\title{
Antiviral and virucidal activities of Duabanga grandiflora leaf extract against Pseudorabies virus in vitro
}

\author{
Farhah Zaidar Abdul Malik', Zeenathul Nazariah Allaudin ${ }^{1 *}$, Hwei San Loh², ${ }^{2,3}$ Ting Kang Nee ${ }^{4}$, \\ Homayoun Hani ${ }^{1}$ and Rasedee Abdullah ${ }^{5}$
}

\begin{abstract}
Background: Duabanga grandiflora or known in Malaysia as Berembang Bukit, Megawasih, or Pedada Bukit, is a native plant of the Southeast Asian countries. In this study, the anti-viral properties of D. grandiflora were investigated.

Methods: The D. grandiflora leaf extracts were obtained with ethyl acetate, hexane, and ethanol as solvents and labelled 37 leaf ethyl acetate (37 L EA), 37 leaf hexane ( $37 \mathrm{~L} \mathrm{H}$ ), 37 leaf ethanol (37 L ET), respectively. The cytotoxicity of the extracts on Vero cells were determined by the 3-(4,5-Diamethylthiazol-2-yl)-2,5-Diphenyltetrazolium Bromide (MTT) assay.

Results: Among extracts, $37 \mathrm{~L}$ EA was most cytotoxic to Vero cells, followed by $37 \mathrm{~L} \mathrm{H}$ and $37 \mathrm{~L}$ ET, with $\mathrm{CC}_{50}$ of 218 , 833 , and $>1000 \mu \mathrm{g} / \mathrm{mL}$, respectively. The cytopathic effect (CPE) and plaque reduction, inhibition, and virucidal assays and the selective index (SI) were employed to determine the effect of the extracts on infectivity and replication of pseudorabies virus (PrV) in Vero cells. The D. grandiflora leaf extracts showed dose-dependent antiviral activities, with higher activities at high doses. The $37 \mathrm{LET}$ and $37 \mathrm{LEA}$ showed anti-viral effects through plaque formation and viral replication inhibitions, and virucidal property. The SI of the $37 \mathrm{~L}$ ET and $37 \mathrm{~L}$ EA by the viral replication inhibition assay was 8.3 and 1.9, respectively, and by the CPE reduction assay, 6.7 and 2.9, respectively.
\end{abstract}

Conclusion: Ethanol is the best solvent for the preparation of D. grandiflora leaf extract as an antiviral agent.

Keywords: Antiviral assay, Duabanga grandiflora, Plaque reduction assay, Inhibition assay, Virucidal assay

\section{Background}

Duabanga, a genus originally included in the Sonneratiaceae, is now classified under the subfamily Duabangoideae of the family Lythraceae. Duabanga, native to Southeast Asia, consists of three species, Duabanga grandiflora, D. moluccana, and D. taylorii Jayaweera [1]. In Malaysia, Duabanga is known as Berembang Bukit, Megawasih and Pedada Bukit. Duabanga grandiflora contains eugeniin, comprising of gallic acid, ellagic acid, and sugar [2].

Traditionally, the Duabanga grandiflora tree has several medicinal properties. The leaf extract is used topically to whiten skin, retard aging, and heal inflammation

\footnotetext{
* Correspondence: zeenathulnazariah@gmail.com

'Department of Veterinary Pathology and Microbiology, Faculty of Veterinary Medicine, Universiti Putra Malaysia, Serdang 43400, Selangor, Malaysia Full list of author information is available at the end of the article
}

through the stimulation of type II collagen production [2]. The D. grandiflora extracts and partial purified fractions exhibited bacterial growth inhibition and re-sensitized methicillin-resistant Staphylococcus aureus (MRSA) towards ampicillin treatment by inhibiting MRSA biofilm formation and the penicillin-binding protein, PBP2a [3-6]. The plant extracts also possess insecticidal activity [7].

The antimicrobial and phytochemical properties of $D$. grandiflora was first described in 2011 [3] in a report that described the use of higher plant species for combating newly emerging and drug resistant pathogens. The ethanol D. grandiflora leaf extract appears to contain a high concentration of phytochemicals including tannins, phenolic compounds, flavonoids and steroids. On the other hand, the ethyl acetate $D$. grandiflora extract contain high level of tannins and moderate levels of alkaloids and phenols [3]. Previously, phytochemicals 
especially tannins, phenolic compounds, flavonoids were reported to possess antiviral activities against human and animal viruses [8-12].

Herpesviruses are highly prevalent in humans and most animals [13]. Members of Herpesviridae are hostspecific agents that share properties, which allow them to cross species barriers $[14,15]$. This group of viruses has relatively short reproduction cycle, can efficiently destroy infected cells, spread rapidly, and establish latent infection in the host.

In this study, the antiviral properties of $D$. grandiflora plant extracts against PrV was determined. The cellular toxicity and the most effective solvent to be used in the preparation of $D$. grandiflora leaf extracts were also determined.

\section{Methods}

\section{Crude plant extract}

D. grandiflora was collected from the Semenyih Dam area $\left(3.079066^{\circ} \mathrm{N} 101.886091^{\circ} \mathrm{E}\right)$, Selangor, Malaysia, identified by Dr. Christopher Wiart of the University of Nottingham, Malaysia Campus, and the herbarium voucher specimens (UNMC 37) deposited at the Herbarium of Faculty of Science of the University. Crude plant extracts, harvested from the leaves, extracted with hexane, ethanol, and ethyl acetate, and labelled 37 L H, 37 L ET, and 37 L EA, respectively were prepared by Dr. Kang Nee Ting and Prof. Dr. Hwei San Loh of the University of Nottingham, Malaysia.

The leaves of the $D$. grandiflora were cleaned with sterile deionized water, cut into small fragments, and dried in a closed room at 25 to $28{ }^{\circ} \mathrm{C}$ for 2 weeks. The dried leave fragments were grounded, weighed and soaked in $95 \%$ ethanol at a proportion of 1:8 (fragment: ethanol) at room temperature for $24 \mathrm{~h}$. The plant materials were then subjected to sequential fractionation using hexane, ethanol, and ethyl acetate. Each plant material was soaked and fractionated trice before subjecting to rotary evaporation at $40{ }^{\circ} \mathrm{C}$ under reduced pressure. The concentrated crude extracts were stored at $-20{ }^{\circ} \mathrm{C}$.

\section{Pseudorabies Virus (PrV) propagation}

The PrV strain AIP used in this study is from the working stock virus $\left(1 \times 10^{8} \mathrm{pfu} / \mathrm{mL}\right)$ prepared and stored at $-80^{\circ} \mathrm{C}$ in the Virology Laboratory, Faculty of Veterinary Medicine, Universiti Putra Malaysia. Quantitation of stock virus was by plaque titration assay using Vero cells.

\section{Vero cell culture}

Vero cells (ATCC No. CCL-81) were grown in RPMI 1640 supplemented with $10 \%$ fetal bovine serum (FBS) and antibiotic-antimycotic combination [1\% Penicillin (100 U/mL), $1 \%$ Streptomycin $(100 \mathrm{mg} / \mathrm{mL})$ and $1 \%$ Fungi zone $(2.5 \mathrm{mg} / \mathrm{mL})]$. The cells were maintained in
RPMI maintenance media supplemented with $1 \%$ FBS, seeded into sterile 96-well flat bottom and 24-well plates at $1 \times 10^{4}$ cells/well, and incubated under $5 \% \mathrm{CO}_{2}$ humidified atmosphere at $37^{\circ} \mathrm{C}$.

\section{Plant extract}

All plant extracts were dissolved, with frequent shaking for $48 \mathrm{~h}$ in dimethyl sulfoxide (DMSO) and then diluted with sterile deionized water to obtain stock concentrations of $10 \mathrm{mg} / \mathrm{mL}$ in $10 \%$ DMSO and $50 \mathrm{mg} / \mathrm{mL}$ in 50 \% DMSO. The $37 \mathrm{~L} \mathrm{ET} \mathrm{extract} \mathrm{was} \mathrm{the} \mathrm{most} \mathrm{soluble}$ followed in order by $37 \mathrm{~L} \mathrm{EA}$, and $37 \mathrm{~L} \mathrm{H}$. The solutions were stored as stock at $-20{ }^{\circ} \mathrm{C}$.

\section{Cytotoxicity assay}

The stock solutions were diluted serially with RPMI media without FBS to obtain extract concentrations of $62.5,125,250,500$, and $1000 \mu \mathrm{g} / \mathrm{mL}$. In general, the final concentration of DMSO in the working concentration was below $0.3 \% .100 \mu \mathrm{L}$ of each concentration was used to treat confluent monolayer Vero cells in a 96-well flatbottom plate. For reference the Vero cells were treated with $100 \mu \mathrm{L}$ of either $0.05,1.0,10$, or $12 \%$ DMSO in PBS. Non-treated Vero cells served as the negative control. Positive controls were treated with DMSO at the same concentrations as the plant extracts. All experiments were performed in triplicates. The Vero cells were then incubated for $48 \mathrm{~h}$ under $5 \% \mathrm{CO}_{2}$, humidified atmosphere at $37{ }^{\circ} \mathrm{C}$ and visualized under light microscopy. The cytotoxic effect of treatments was determined by MTT assay. Cytotoxicity scoring was according a 5point scale: $5=$ confluent well-defined monolayer with cell-to-cell contact and the cell morphology and density intact; 4 =occasional cell lysis with $\leq 20 \%$ of the cells round in shape, loosely attached, devoid of intracytoplasmic granule; $3=$ prevalent cell lysis with $<50 \%$ of cells round in shape and devoid of intracytoplasmic granule; $2=$ the majority of the cells are affected but $<70 \%$ of cells are round in shape or lysed; $1=$ almost total lysis and destruction of cells and presence of spaces between cells [16]. The cytotoxic concentrations $\left(\mathrm{CC}_{50}\right)$ of crude plant extracts, which are the concentrations causing $50 \%$ cell cytotoxicity of Vero cells were determined (Additional file 1).

\section{Antiviral assays \\ Cytopathic Effect (CPE) reduction assay}

The CPE reduction assay was conducted according to method described previously [17]. The Vero cells were seeded in a 96-well flat-bottom plate for $24 \mathrm{~h}$ to obtain a monolayer. $50 \mu \mathrm{L}$ of $50 \mathrm{TCID}_{50} \mathrm{PrV}$ with $50 \mu \mathrm{L}$ of either $18.75,37.5,75,150$, or $300 \mu \mathrm{g} / \mathrm{mL}$ extracts was added to the cells and incubated under $5 \% \mathrm{CO}_{2}$ at $37{ }^{\circ} \mathrm{C}$ for $72 \mathrm{~h}$. The CPE was determined under light microscopy and 
graded as follows: $0=0 \%, 1=0$ to $25 \%, 2=26$ to $50 \%$, $3=51$ to $75 \%$, and $4=76$ to $100 \%$ CPE. The percentage $\mathrm{CPE}$ inhibition was calculated using the following formula: $\%$ inhibition $=\left(\mathrm{CPE}_{\text {exp }} / \mathrm{CPE}_{\text {control }}\right) \times 100$, to determine the $50 \%$ effect concentration $\left(\mathrm{EC}_{50}\right)$ of the extracts where $\mathrm{CPE}_{\exp }=\mathrm{CPE}$ of extract and $\mathrm{CPE}_{\text {control }}=\mathrm{CPE}$ of virus control.

\section{Plaque reduction assay}

Plaque reduction assay was conducted according to the method described by Hsuan et al. [18]. Briefly, confluent monolayers of Vero cells were grown in 24-well plates. $100 \mu \mathrm{L}$ of extracts at either $62.5,125,250,500 \mu \mathrm{g} / \mathrm{mL}$ or $100 \mu \mathrm{L}$ of $100 \mathrm{pfu} \mathrm{PrV}$ were added to the monolayer Vero cells and incubated for 90 min under $5 \% \mathrm{CO}_{2}$ at $37{ }^{\circ} \mathrm{C}$. Cells treated virus but not with plant extract served as the positive control while those not treated with either virus or extract served as the negative control. The incubating solution contain virus and extract was discarded and $1 \mathrm{~mL} 1 \%$ methylcellulose in DMEM containing $2 \%$ FBS added to the cells and the plates incubated under $5 \% \mathrm{CO}_{2}$ for $48 \mathrm{~h}$ at $37{ }^{\circ} \mathrm{C}$. The infected cells were fixed with $10 \%$ formal saline, stained with $0.5 \%$ crystal violet solution, and the plaques counted. The $50 \%$ plague inhibition concentration $\left(\mathrm{IC}_{50}\right)$ was determined by the following formula [19]: \% inhibition $=\left[1-\left(\mathrm{pfu}_{\exp } / \mathrm{pfu}_{\mathrm{control}}\right)\right] \times 100$, where $\mathrm{pfu}_{\exp }=$ plague formation by extract-and virus-treated cells and $\mathrm{pfu}_{\mathrm{control}}=$ plague formation by virus-treated cells.

\section{Inhibition assay on viral replication}

The viral replication inhibition assay was according to that described previously [20]. $100 \mu \mathrm{L}$ of 100pfu PrV were incubated with the monolayer Vero cells in a 24well flat-bottom plate under $5 \% \mathrm{CO}_{2}$ at $37{ }^{\circ} \mathrm{C}$ for $90 \mathrm{~min}$. The incubating solution was discarded, the cells treated with $0.5 \mathrm{~mL}$ of either $25,50,100$, or $200 \mu \mathrm{g} / \mathrm{mL}$ extract in $1 \%$ methylcellulose and reincubated under $5 \% \mathrm{CO}_{2}$ at $37{ }^{\circ} \mathrm{C}$ for $48 \mathrm{~h}$. The infected cells were fixed with $10 \%$ formal saline and stained with $0.5 \%$ crystal violet solution. The plaques were counted and the $\mathrm{IC}_{50}$ calculated as described in plaque reduction assay.

\section{Determination of extracellular virucidal assay}

The extracellular virucidal activity of extracts on PrV was performed according to the method described by Carlucci et al. [21]. Monolayer Vero cells were treated with $5 \times 10^{6} \mathrm{pfu} \operatorname{PrV}$ and $100 \mu \mathrm{L}$ of either $62.5,125,250$, or $500 \mu \mathrm{g} / \mathrm{mL}$ extract and incubated at $25^{\circ} \mathrm{C}$ for $6 \mathrm{~h}$, followed by 10 -fold serial dilution. $100 \mu \mathrm{L}$ mixture of equal amounts of virus $\left(50 \mu \mathrm{L}\right.$ of $\left.1 \times 10^{8} / \mathrm{mL}\right)$ and extract $(50 \mu \mathrm{L})$ in $2 \% \mathrm{FBS} / \mathrm{DMEM}$ was incubated under $5 \% \mathrm{CO}_{2}$ for $90 \mathrm{~min}$ at $37{ }^{\circ} \mathrm{C}$. The incubating solution containing virus and extract was discarded, $0.5 \mathrm{~mL}$ of $1 \%$ methylcellulose in $2 \% \mathrm{FBS} / \mathrm{DMEM}$ was added to the cells and the plate incubated under $5 \% \mathrm{CO}_{2}$ at $37{ }^{\circ} \mathrm{C}$ for $48 \mathrm{~h}$. The plaques formed were fixed with $10 \%$ formal saline and stained with $0.5 \%$ crystal violet solution for $30 \mathrm{~min}$ and counted. Residual virus infectivity was determined according the following formula: plague formation $(\mathrm{pfu})=$ Number of plaques $\times[1 /$ viral inoculation $] \times[1 /$ dilution fold]. The $\mathrm{IC}_{50}$ of extracts of plaque inhibition was calculated as follows: $\mathrm{IC}_{50}=\left(\mathrm{pfu}_{\text {exp }} / \mathrm{pfu}_{\text {control }}\right) \times 100$, where $\mathrm{pfu}_{\mathrm{exp}}=$ plague formation by extract- and virus-treated cells and $\mathrm{pfu}_{\mathrm{control}}=$ plague formation by virus-treated cells.

\section{Data analysis}

All values are expressed as mean \pm standard deviation. The $\mathrm{CC}_{50}, \mathrm{EC}_{50}$, and $\mathrm{IC}_{50}$ values were estimated by extrapolating the graph plotted with software Microsoft Excel 2007. Mean values were compared using multiple comparison Tukey test with the SPSS 6.0 software. The difference was statistically significant when $p<0.05$.

\section{Results}

\section{Cytotoxicity assay}

The $\mathrm{CC}_{50}$ of $37 \mathrm{~L}$ EA and $37 \mathrm{~L} \mathrm{H}$ on Vero cells was 213 and $813 \mu \mathrm{g} / \mathrm{mL}$, respectively. For $37 \mathrm{~L} \mathrm{ET,} \mathrm{the} \mathrm{CC}_{50}$ was $>1000 \mu \mathrm{g} / \mathrm{mL}$ with $<50 \%$ cytotoxicity (Table 1, Figs. 1 and 2). The $37 \mathrm{~L} \mathrm{H}$ and $37 \mathrm{~L} \mathrm{EA}$ extracts were significantly $(p<0.05)$ more cytotoxic than 37 L ET extract to Vero cells.

\section{Antiviral assay}

\section{CPE reduction assay}

The anti-PrV activity of D. grandiflora leaf extracts were evaluated by the CPE reduction assay after $72 \mathrm{~h}$ of incubation. The $37 \mathrm{EA}$ and $37 \mathrm{ET}$ extracts showed a dosedependent effect in PrV-induced CPE on Vero cells with $\mathrm{EC}_{50}$ of 75 and $150 \mu \mathrm{g} / \mathrm{mL}$, respectively (Fig. 3). The $37 \mathrm{~L} \mathrm{H}$ extract did not show the same effect.

Table 1 Cytotoxicity scoring of

\begin{tabular}{lccc}
\hline $\begin{array}{l}\text { Conc. } \\
(\mu \mathrm{g} / \mathrm{mL})\end{array}$ & \multicolumn{4}{c}{ D. grandiflora leaf extract } \\
\cline { 2 - 4 } & $37 \mathrm{LH}$ & $37 \mathrm{LET}$ & $37 \mathrm{LEA}$ \\
\hline 62.5 & 3 & 3 & 3 \\
125 & 3 & 3 & 3 \\
250 & 3 & 2 & $2^{\mathrm{a}}$ \\
500 & 2 & 2 & 2 \\
1000 & $2^{\mathrm{a}}$ & $2^{\mathrm{a}}$ & 2
\end{tabular}

${ }^{\mathrm{a}}$ Scored for concentration near to $\mathrm{CC}_{50}$. Score $1=$ severely cytotoxic. Almost complete cell destruction and lysis of the cells ( $100 \%$ of cells were lysed), $2=$ significantly cytotoxic ( $70 \%$ of cells were lysed), $3=$ moderately cytotoxic ( $\sim 50 \%$ of cells were rounded), $4=$ mildly cytotoxic. Approximately $20 \%$ of cells appear rounded, loosely attached, without intracytoplasmic granules, $5=$ noncytotoxic ( 100\% of culture flask surface were covered by cells). 37 L H, 37 L ET, and $37 \mathrm{~L}$ hexane, ethanol, and ethyl acetate extract, respectively 


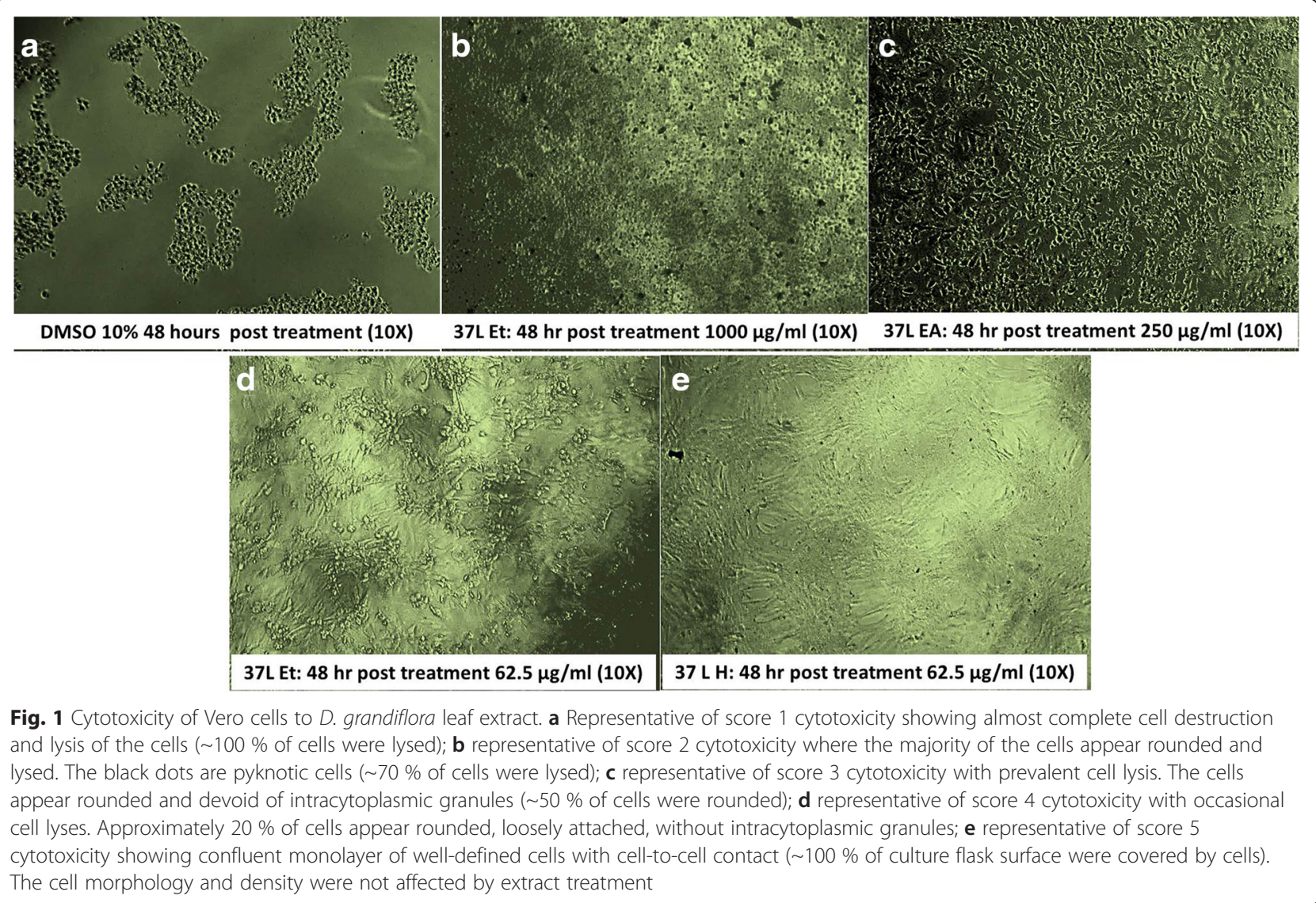

\section{Plaque reduction assay}

In the plaque reduction assay, the Vero cells were infected with $100 \mathrm{pfu}$ of $\operatorname{PrV}$ and $100 \mu \mathrm{L}$ of either 62.5, 125, 250, or $500 \mu \mathrm{g} / \mathrm{mL}$ plant extract. Extracts $37 \mathrm{~L} \mathrm{ET}$ and $37 \mathrm{~L}$ EA caused reduction in plaque formation with $37 \mathrm{~L}$ ET and $37 \mathrm{~L}$ EA causing $100 \%$ reduction at 250 and $500 \mu \mathrm{g} / \mathrm{mL}$, respectively (Fig. 4). However, $37 \mathrm{~L} \mathrm{H}$ did not produce any effect on the Vero cells.

\section{Viral replication inhibition assay}

The Vero cells were infected with $\operatorname{PrV}$ for $90 \mathrm{~min}$ and then treated with either $25,50,100$, or $200 \mu \mathrm{g} / \mathrm{mL} D$. grandiflora leaf extracts to determine their effect on virus replication. The results showed that $37 \mathrm{~L} \mathrm{H}$ did not inhibit plaque formation. However, $200 \mu \mathrm{g} / \mathrm{mL} 37 \mathrm{~L}$ Et and $37 \mathrm{~L}$ EA caused complete inhibition in plaque formation indicating total inhibition of viral replication in Vero cells (Fig. 5).

\section{Virucidal activity}

D. grandiflora leaf extracts were incubated with $\operatorname{PrV}$ to determine their effect on the virus and its residual infectivity. The results showed that $37 \mathrm{~L} \mathrm{EA}$ at $62.5 \mu \mathrm{g} / \mathrm{mL}$ had no residual viral infectivity in the Vero cells indicating total viral inactivation. The $37 \mathrm{~L}$ ET only had slight residual infectivity of $1.3 \%$ that is translated as $98.7 \%$ viral inactivation. On the other hand, $37 \mathrm{~L} \mathrm{H}$ produced $100 \%$ residual infectivity indicating no inhibitory effect on the viral replication in Vero cells (Fig. 6).

The selective index (SI) $\left[\mathrm{CC}_{50} / \mathrm{IC}_{50}\right]$ was estimated by the viral inhibition and CPE assays. Based on the SI, 37 L ET extract has the highest antiviral potential while $37 \mathrm{~L} \mathrm{H}$ extract had the lowest.

These results showed that ethanol is the best solvent for the extraction of compounds with virucidal properties from D. grandiflora leaves (Fig. 7).

\section{Discussion}

The study showed that the cytotoxicity of $D$. grandiflora leaf extracts increased with concentration and this is attributed to their bioactive compound content. It was earlier shown that chloroform $D$. grandiflora extract contains 3 triterpenes, 3 flavones, 4 phenolic compounds and 1 steroids [22]. Some of these compounds and their derivatives possess antimicrobial properties [7]. In this study, we determined the antiviral activity of the $D$. grandiflora leaf extract obtained by using hexane, ethanol, and ethyl acetate as solvents. It appears that the ethanol $D$. grandiflora leaf extract had the highest antiviral activity while being less toxic to Vero cells than either the hexane or ethanol extract. 


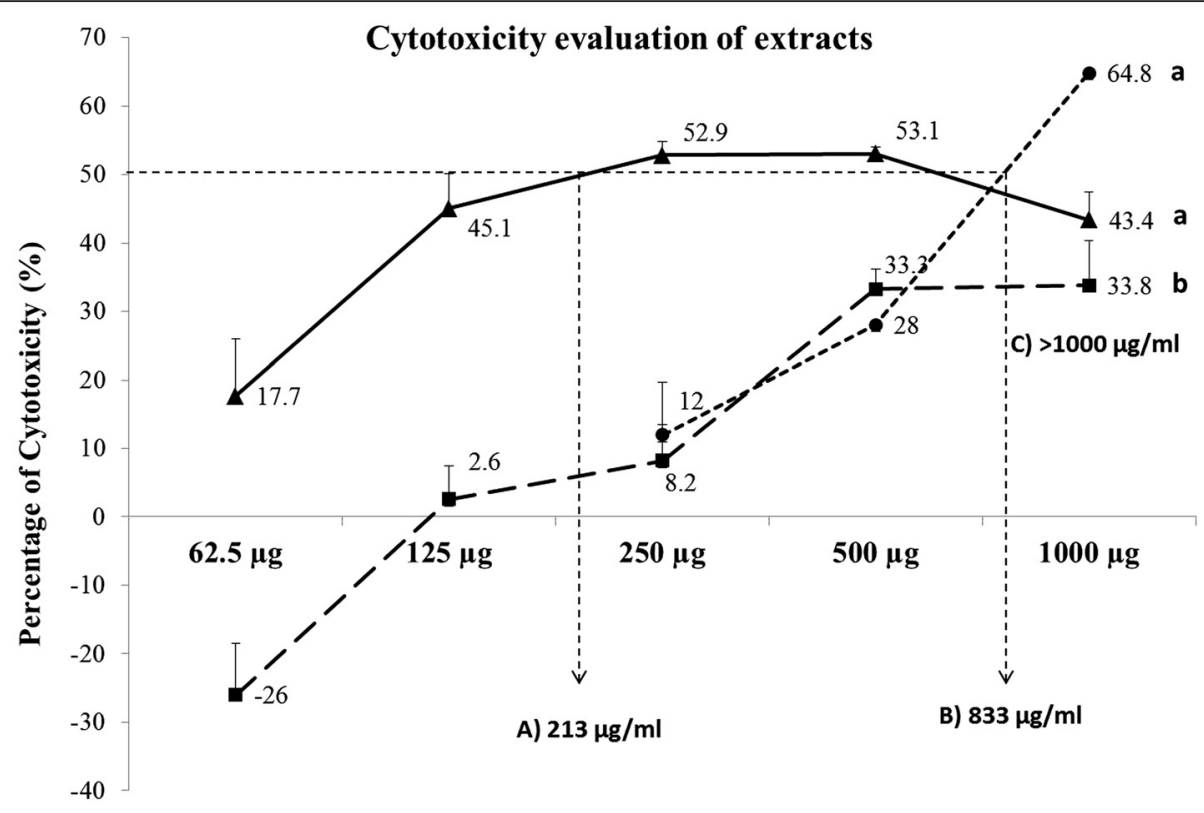

Extracts Concentration $(\mu \mathrm{g} / \mathrm{ml})$

$-\bullet-37 \mathrm{~L} \mathrm{H} \rightarrow-37 \mathrm{~L} \mathrm{ET} \leftarrow-37 \mathrm{~L} \mathrm{EA}$

Fig. 2 Determination of $I C_{50}$ of D. grandiflora leaf extract on Vero cells. The $\mathrm{CC}_{50}$ of Vero cell treated with $37 \mathrm{~L} E A, 37 \mathrm{~L} H$, and $37 \mathrm{~L}$ ET was 213 , 833 , and $>1000 \mu \mathrm{g} / \mathrm{mL}$, respectively. "a and b" letter indicate significant difference between individual extracts at $p<0.05$

\section{CPE reduction assay}

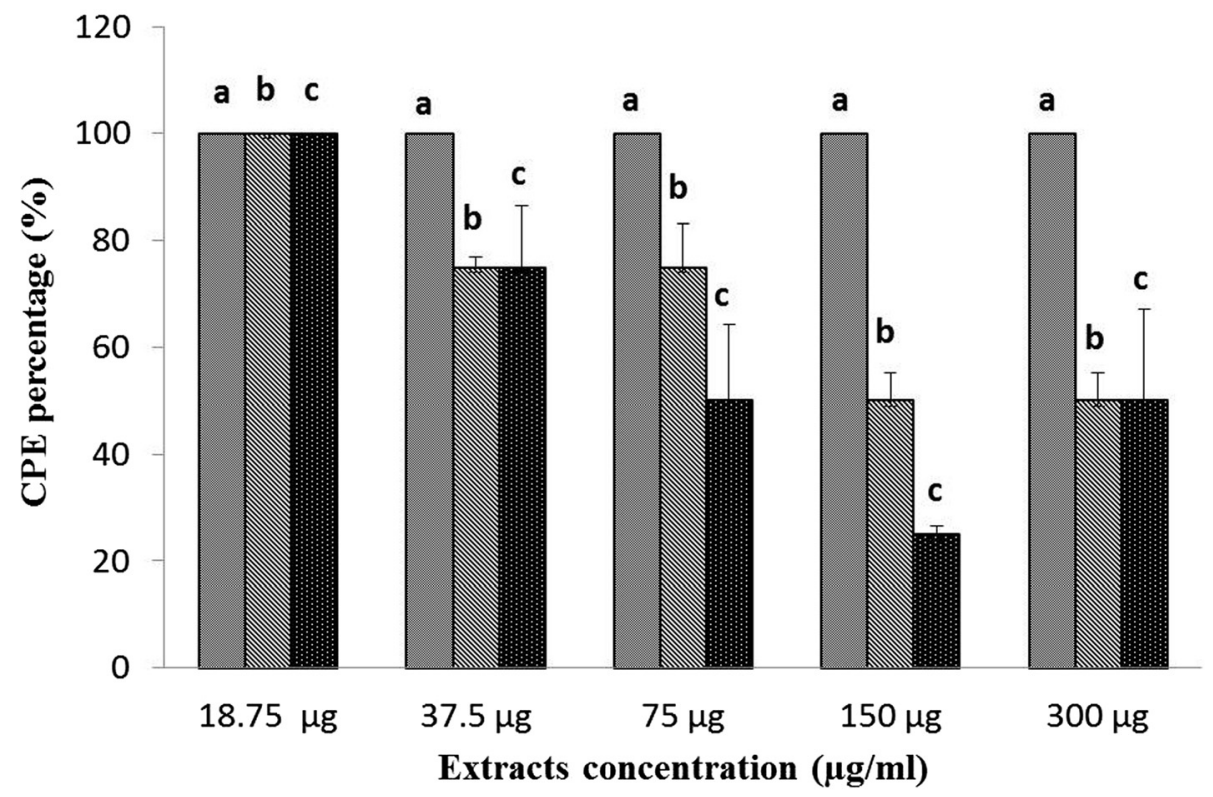

37L H $\quad$ 37LET $37 \mathrm{LEA}$

Fig. 3 Effect of D. grandiflora leaf extracts on PrV-induced cytopathic effect on Vero cells. a,b,c indicate significant difference between individual extracts in each concentration at $p<0.05$ 


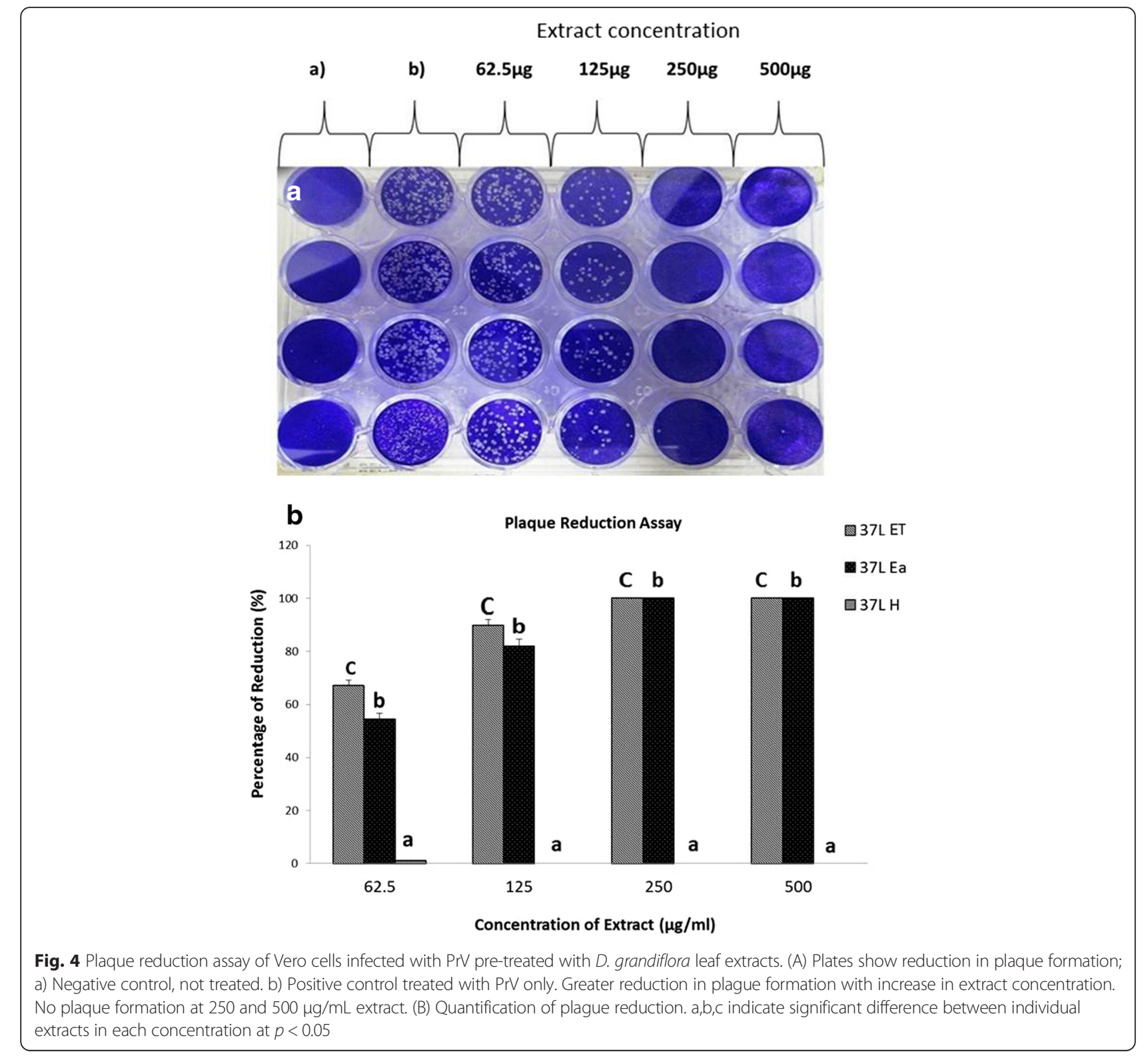

DMSO usage as diluent of extracts at concentrations of less $10 \%$ is not cytotoxic [23]. Our study showed that $0.1 \%$ DMSO produced approximately $3 \%$ Vero cell toxicity. Thus, at this concentration, DMSO did not contribute significantly to the cytotoxic effect of $D$. grandiflora leaf extract.

Many plants extracts have been shown to inhibit or inactivate virus replication. Among extracts with antiviral properties is the Isatis indigotica extract that produced a dose-dependent inhibition of $\operatorname{PrV}$ replication in vitro [18] and the Geranium sanguineum extracts that inhibit herpesvirus infection by causing perturbations in the early stages of virus replication [17]. D. grandiflora leaf extracts seems to have similar antiviral potentials. It was shown in this study that the extract inhibits viral infection via the cytopathic effect, plaque reduction, viral replication, and virucidal activities. However, the antiviral activities of the $D$. grandiflora leaf extracts are dependent on the solvent used in the preparation of the extract. The hexane extract did not have any inhibitory activity towards PrV. Based on the CPE, virus inhibition and virucidal assays, the ethanol and ethyl acetate $D$. grandiflora leaf extracts have equal virucidal and inactivation activity before the PrV could infect Vero cells [24]. The CPE of the extracts is dose-dependent with the most effective antiviral concentrations assumed to be from 150 to $<300 \mu \mathrm{g} / \mathrm{mL}$. Increasing the extraction concentration to $300 \mu \mathrm{g} / \mathrm{mL}$ did not seem to improve the antiviral effect of either the ethanol or ethyl acetate $D$. grandiflora leaf extract. 


\section{Extracts concentration}

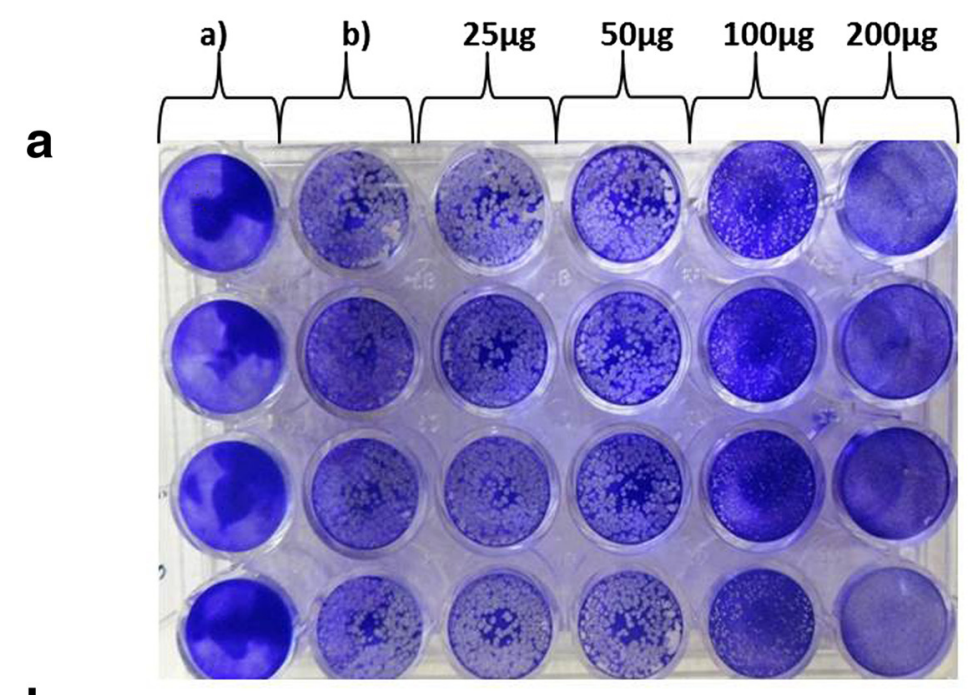

b

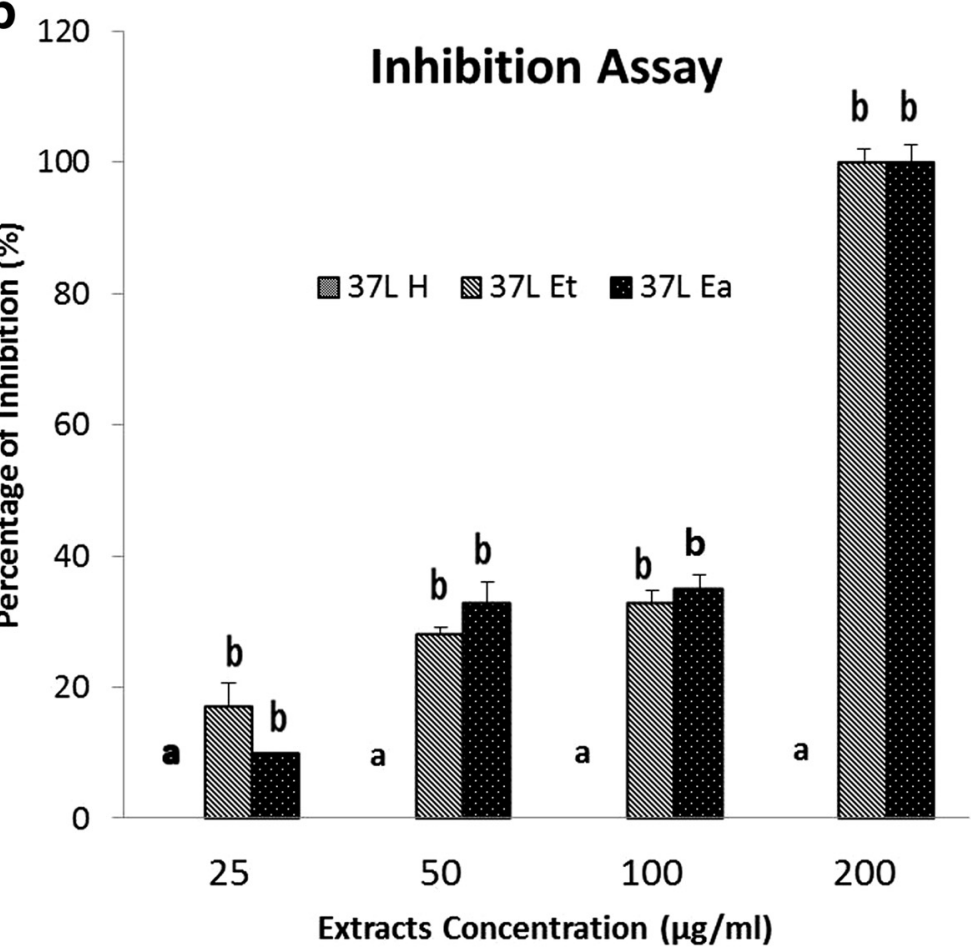

Fig. 5 Inhibition of viral replication in PrV-infected Vero cells after treatment with D. grandiflora leaf extract. a Plates show reduction in plaque numbers in extract-treated PrV-infected cells; a) Negative control, untreated, without plaque formation, b) Positive control, PrV-treated only. The number of plaque decreased with increase in extract concentration. $\mathbf{b}$ Quantification of plague inhibition by $D$. grandiflora leaf extract by difference solvents on PrV replication. a,b indicate significant difference between individual extracts in each concentration at $p<0.05$

The D. grandiflora leaf extracts seemed to inhibit PrV infection of Vero cells. This is clearly evident by the plaque reduction assay where extract treatment prevented Vero cell plague formation, particular at concentrations of $\geq 250 \mu \mathrm{g} / \mathrm{mL}$. In fact, all $D$. grandiflora leaf extracts prevented PrV infection of Vero cells. However, it should be noted that in in vitro experiments, viral infection of cells is dependent on factors such as virus concentration and incubation period for viral infection. In this study, the virus concentrations and incubation periods for $\mathrm{CPE}$ and plague reduction assays were variable. In the CPE assay, although the incubation period was longer, less virus was used than in the plague reduction assay. For that reason, the results from the two 


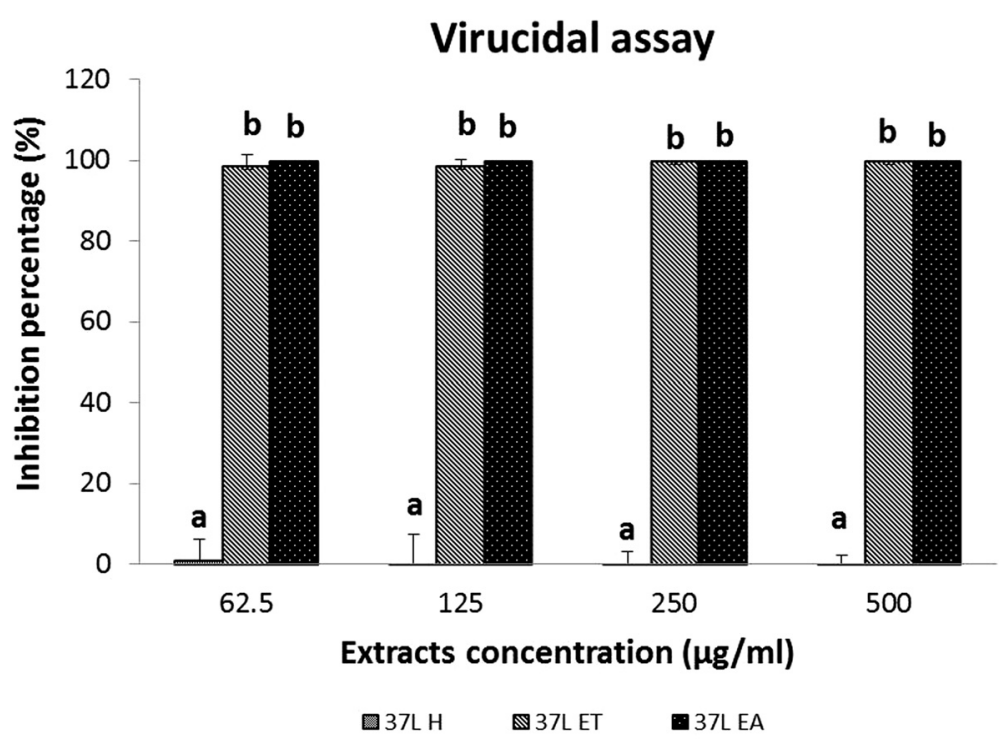

Fig. 6 Virucidal effect of D. grandiflora leaf extracts. a, b indicate significant difference between individual extracts in each concentration at $p<0.05$

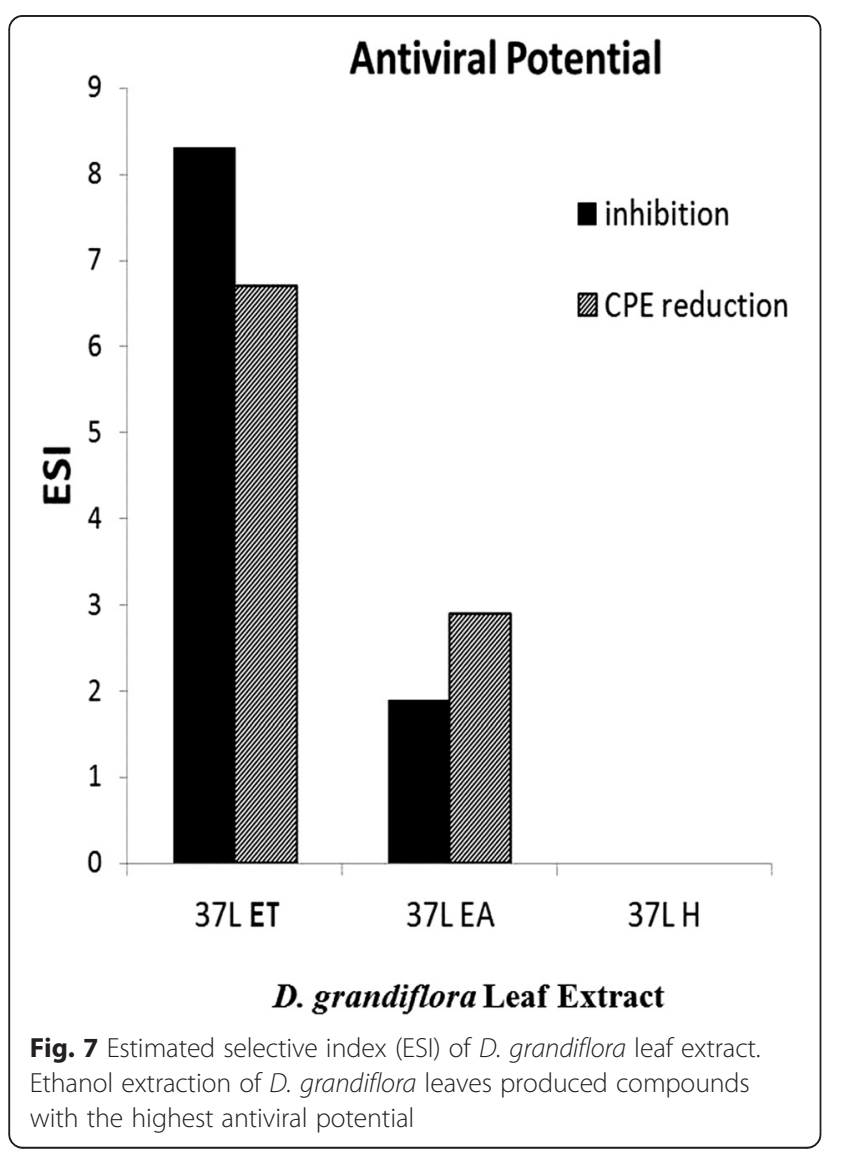

assays were not completely complimentary. There was total inhibition of plague formation in infected Vero cells treated with high concentrations of ethanol and ethyl acetate $D$. grandiflora leaf extracts while the cytopathic effect was between 20 and $50 \%$.

In the evaluation of virucidal activity, the PrV were pre-incubated with D. grandiflora leaf extracts for $6 \mathrm{~h}$ before infecting Vero cells. The antiviral effect of the extracts was determined by the viral residual infectivity in Vero cells. The ethanol D. grandiflora leaf extract at all concentrations used in the study almost completely inhibited plague formation. To confirm the antiviral potential of the extracts, the SI was calculated. A high SI suggests that the extract would has good antiviral properties. In this study, the ethanol had at least twice as high SI than the ethyl acetate $D$. grandiflora leaf extract. Based on these results, the ethanol D. grandiflora leaf extract is most appropriate to be developed into a therapeutic compound for viral diseases.

The efficacy of anti-viral drugs can be determined by their $\mathrm{IC}_{50}$ on Vero cells. The anti-herpesvirus drug, Acyclovir for example, has an $\mathrm{IC}_{50}$ of 0.8 to $0.9 \mu \mathrm{g} / \mathrm{mL}$ on Vero cells $[25,26]$. The ethanol and ethyl acetate $D$. grandiflora leaf extracts was shown to have much lower $\mathrm{IC}_{50}$ than Acyclovir at 0.12 and $0.112 \mu \mathrm{g} / \mathrm{mL}$, respectively suggesting that the $D$. grandiflora leaf extracts are more efficacious in the treatment of herpesvirus infections than Acyclovir.

The antiviral activities of the ethanol and ethyl acetate D. grandiflora extracts are attributed to their phytochemical contents [3], particularly tannins, phenolic compounds, flavonoids, and alkaloids that may act synergistically. Among the advantages of crude extracts as 
antiviral agents are their greater potency, fewer side effects and toxicity, and cost-effectiveness [27-29]. Although, further studies would be of interest to determine whether the components of the $D$. grandiflora leaf extracts have synergistic effects, this does not detract from fact that the extracts have effective anti-herpesvirus properties.

\section{Conclusion}

The ethanol $D$. grandiflora leaf extracts while showing the least cytotoxic effect towardsVero cells, is the most efficacious anti-viral agent among the $D$. grandiflora leaf extracts investigated in this study. The wide safety margin, low cytotoxicity and high selective index make the ethanol D. grandiflora leaf extract a prime candidate for development as an anti-viral agent.

\section{Additional file}

Additional file 1: Supplementary document DMSO Cytotoxicity assay.

(JPG $40 \mathrm{~kb}$ )

\section{Abbreviations}

ATCC: American Type Culture Collection; $\mathrm{CC}_{50}$ : the cytotoxic concentrations CPE: cytopathic effect; DMEM: Dulbecco modified Eagle medium; DMSO: dimethyl sulfoxide; EA: ethyl acetate; $\mathrm{EC}_{50}$ : $50 \%$ effect concentration; ET: ethanol; FBS: fetal bovine serum; $H$ : hexane; $\mathrm{IC}_{50}$ : $50 \%$ inhibitory concentration; MRSA: methicillin-resistant Staphylococcus aureus; MTT: 3-(4,5Diamethylthiazol-2-yl)-2,5-Diphenyltetrazolium Bromide; PBP2a: penicillin-binding protein; PFU: plaque forming unit; PrV: Pseudorabies virus; RPMl: Roswell Park Memorial Institute; SI: selective index; TCID 50 : 50 \% tissue culture infective dose.

\section{Acknowledgments}

The authors would like to thank and acknowledge the Ministry of Science and Technology of Malaysia (MOSTI) for providing financial support under the research Project number 03-02-04-0563-SR0008/05-06. In addition, we thank Universiti Putra Malaysia for providing the research environment and necessary facilities.

\section{Funding}

Financial support under the research Project number 03-02-04-0563-SR0008/ 0506 by the Ministry of Science and Technology of Malaysia (MOSTI).

\section{Availability of data and materials}

The data set was deposited in publicly available repositories The data set was deposited in publicly available repositories (http://dx.doi.org/10.6070/ H4(V4FSP).

\section{Authors' contributions}

FZAM: Carried out data collection, analysis and preparation of manuscript draft. ZNA: Supervised the study, was project leader and helped to draft the manuscript. HSL: has made substantial contributions to conception, design and virological experimentation. TKN: has made substantial contributions to conception and design, has given final approval of the version to be published. $\mathrm{HH}$ : has been involved in drafting the manuscript and revising it critically for important intellectual content; has given final approval of the version to be published. RA: has been involved revising the manuscript critically for important intellectual content; has given final approval of the version to be published. All authors read and approved the final manuscript.

\section{Competing interests}

The authors declare that they have no competing interests.

\section{Consent for publication}

This information is not relevant.
Ethics approval and consent to participate

his information is not relevant.

\section{Author details}

${ }^{1}$ Department of Veterinary Pathology and Microbiology, Faculty of Veterinary Medicine, Universiti Putra Malaysia, Serdang 43400, Selangor, Malaysia.

${ }^{2}$ School of Biosciences, Faculty of Science, University of Nottingham Malaysia Campus, Jalan Broga, 43500 Semenyih, Selangor, Malaysia. ${ }^{3}$ Biotechnology Research Centre, The University of Nottingham Malaysia Campus, Semenyih, Selangor, Malaysia. ${ }^{4}$ Department of Biomedical Sciences, Faculty of Science, The University of Nottingham Malaysia Campus, Semenyih, Selangor, Malaysia. ${ }^{5}$ Department of Veterinary Laboratory Diagnostics, Faculty of Veterinary Medicine, Universiti Putra Malaysia, Serdang 43400, Selangor, Malaysia.

Received: 13 November 2015 Accepted: 13 May 2016

Published online: 23 May 2016

\section{References}

1. Shi S, Huang Y, Tan F, He X, Boufford DE. Phylogenetic analysis of the Sonneraiaceae and its relationship to Lythraceae based on its sequence of nrDNA. J Plant Res. 2000;113(3):253-8.

2. Tsukiyama M, Sugita T, Kikuchi H, Yasuda Y, Arashima M, Okumura H, Lhiechaiphant S, Shoyama Y. Effects of Duabanga grandiflora for human skin cells. Am J Chin Med. 2010;38(2):387-99.

3. Othman M, Genapathya S, Liew PS, Ch'ng QT, Loh HS, Khoo TJ, Wiart C, Ting KN. Search for antibacterial agents from Malaysian rainforest and tropical plants. Nat Prod Res. 2011;25(19):1857-64.

4. Othman M, Loh HS, Wiart C, Khoo TJ, Lim KH, Ting KN. Optimal methods for evaluating antimicrobial activities from plant extracts. J Microbiol Methods. 2011;84(2):161-6.

5. Santiago C, Lim KH, Loh HS, Ting KN. Inhibitory effect of Duabanga grandiflora on MRSA biofilm formation via prevention of cell-surface attachment and PBP2a production. Molecules. 2015;20(3):4473-82.

6. Santiago C, Pang EL, Lim KH, Loh HS, Ting KN. Inhibition of penicillin-binding protein 2a (PBP2a) in methicillin resistant Staphylococcus aureus (MRSA) by combination of ampicillin and a bioactive fraction from Duabanga grandiflora. BMC Complement Altern Med. 2015;15:178.

7. Aumcharoen W, Chandrapatya A, Kijjoa A, Kainoh Y. Toxicity and repellency activities of the crude methanol extract of Duabanga grandiflora (Lythraceae) against Sitophillus oryzae (Coleoptera: Curculionidae). Pak J Zool. 2012;44(1):227-32.

8. Kumar V, Murugesan S, Bhuvaneswari S. Phytochemical analysis of red alga Champia parvula (C. Agardh) collected from Mandapam coast of Tamil Nadu, India. Int J Adv Pharm. 2015;4(3):15-20.

9. Chávez JH, Leal PC, Yunes RA, Nunes RJ, Barardi CR, Pinto AR, Simões CM, Zanetti CR. Evaluation of antiviral activity of phenolic compounds and derivatives against rabies virus. Vet Microbiol. 2006;116(1):53-9.

10. Kumar S, Pandey AK. Chemistry and biological activities of flavonoids: an overview. Scientific World Journal. 2013:29:2013.

11. Kumar SS, Kumar Y, Khan MS, Anbu J, De Clercq E. Antihistaminic and antiviral activities of steroids of Turbinaria conoides. Nat Prod Res. 2011; 25(7):723-9.

12. Özçelik B, Kartal M, Orhan I. Cytotoxicity, antiviral and antimicrobial activities of alkaloids, flavonoids, and phenolic acids. Pharm Biol. 2011;49(4):396-402.

13. Zuckerman JN. Principles and practice of travel medicine. 2nd Ed, West Sussex, UK: Wiley-Blackwell; 2013.

14. Foster SC, Azar DT, Dohlman CH. Smolin and Thoft's The Cornea: scientific foundations and clinical practice. 4th ed, Philadelphia, PA, USA: Lippincott Williams \& Wilkins; 2005

15. Woźniakowski G, Samorek-Salamonowicz E. Animal herpesviruses and their zoonotic potential for cross-species infection. Ann Agric Environ Med. 2015; 22(2):191-4

16. Bhatia SK, Yetter AB. Correlation of visual in vitro cytotoxicity ratings of biomaterials with quantitative in vitro cell viability measurements. Cell Biol Toxicol. 2008;24(4):315-9.

17. Serkedijieva J, Ivancheva S. Antiherpes virus activity of extracts from medicinal plant Geranium sanguineum L. J Etnopharmacol. 1999;64(1):59-68.

18. Hsuan SL, Chang SC, Wang SY, Liao TL, Jong TT, Chien MS, Lee WC, Chen SS, Liao JW. The cytotoxicity to leukemia cells and antiviral effects of Isatis Indigotica extracts on pseudorabies virus. J Ethnopharmacol. 2009;123:61-7. 
19. Liu L, Wen K, Li J, Hu D, Huang Y, Qiu L, Cai J, Che X. Comparison of plaque- and enzyme-linked immunospot-based assays to measure the neutralizing activities of monoclonal antibodies specific to domain iii of dengue virus envelope protein. Clin Vaccine Immunol. 2011;19(1):73-8.

20. Baer A, Kehn-Hall K. Viral concentration determination through plaque assays: using traditional and novel overlay systems. J Vis Exp. 2014;93: e52065.

21. Carlucci MJ, Pujol CA, Cianca M, Noseda MD, Matulewicz MC, Damonte EB, Cerezo AS. Antiherpetic and anticoagulant properties of carrageenans from the red seaweed Gigartina skottsbergii and their cyclized derivatives: correlation between structure and biological activity. Int J Biol Macromol. 1997;20:97-105.

22. Aumcharoen W, Chandrapatya A, Kijjoa A, Silva AMS, Herz W. Chemical constituents of Duabanga grandiflora (Lythraceae). Biochem Syst Ecol. 2009; 37:535-7.

23. Da Violante G, Zerrouk N, Richard I, Provot G, Chaumeil JC, Arnaud P. Evaluation of the cytotoxicity effect of dimethyl sulfoxide (DMSOo) on Caco2/TC7 colon tumor cell cultures. Biol Pharm Bull. 2002;25(12):1600-3.

24. Carlucci MJ, Ciancia M, Matulewiez MC, Carezo AS, Damonte EB. Antiherpetic activity and mode of action of natural carrageenans of diverse structural types. Antiviral Res. 1999;43:93-102.

25. De Clerca E. Comparative efficacy of antiherpes drugs in different cell lines. Antimicrob Agents Chemother. 1982;21(4):661-3.

26. Cheng HY, Lin CC, Lin TC. Antiherpes simplex virus type 2 activity of casuarinin from the bark of Terminalia arjuna Linn. Antiviral Res. 2002;55:445-7.

27. Sood R, Swarup D, Bhatia S, Kulkarni DD, Dey S, Saini M, Dubey SC. Antiviral activity of crude extracts of Eugenia jambolana Lam. against highly pathogenic avian influenza (H5N1) virus. Indian J Exp Biol. 2012;50:179-86.

28. Rajasekaran D, Palombo EA, Yeo TC, Ley DL, Tu CL, Malherbe F, Grollo L. Evidence of synergistic activity of medicinal plant extracts against neuraminidase inhibitor resistant strains of influenza viruses. Adv Microbiol. 2014;4(16):1260

29. Apriyanto DR, Aoki C, Hartati S, Hanafi M, Kardono LB, Arsianti A, Louisa M, Sudiro TM, Dewi BE, Sudarmono P, Soebandrio A. Anti-hepatitis C virus activity of a crude extract from longan (Dimocarpus longan Lour.) leaves. Jpn J Infect Dis. 2015; doi: 10.7883/yoken.JJID.2015.107.

\section{Submit your next manuscript to BioMed Central and we will help you at every step:}

- We accept pre-submission inquiries

- Our selector tool helps you to find the most relevant journal

- We provide round the clock customer support

- Convenient online submission

- Thorough peer review

- Inclusion in PubMed and all major indexing services

- Maximum visibility for your research

Submit your manuscript at www.biomedcentral.com/submit 